\title{
PENERIMAAN KHALAYAK PADA KAMPANYE AUDIO VISUAL: ANALISIS RESEPSI IKLAN ANIES-SANDI PILGUB JAKARTA 2017
}

\author{
Muhammad Irawan Saputra, Dewanto Putra Fajar, M. Fikri AR \\ Jurusan Ilmu Komunikasi, FISIP, Universitas Brawijaya \\ Jl. Veteran, Malang 65145, Jawa Timur, Indonesia \\ m.irawans@ub.ac.id
}

\begin{abstract}
Nowadays, industry and politicians often use audio visuals to package their messages on an advertisement. For example, the election of the Governor of DKI Jakarta, where one of the candidates uses a video campaign on YouTube. This media has been dominated by a juvenile audience that can be categorized as swing voters in political concepts. Therefore, this study aims to find out how audio visual campaigns can be accepted by swing voters. Researcher used the Reception Analysis method to see how the audience received media exposure. The results of this study indicate that Anies-Sandi campaign ads are interpreted as egalitarian by the audience, and are able to display SARA problems with the concepts of harmony and tolerance. However, the Anies-Sandi campaign ad does not have a clear message because the message that delivered is very conceptual.
\end{abstract}

Keywords: Audio Visual Advertising, Reception Analysis, Political Campaign

\begin{abstract}
Abstrak
Saat ini industri dan para politisi kerap menggunakan audio visual untuk mengemas pesan mereka pada sebuah iklan. Sebagai contoh, salah satu konteks penggunaan iklan Audio Visual adalah saat pemilihan Gubernur DKI Jakarta tahun 2017, dimana salah satu kandidatnya yaitu Anies-Sandi menggunakan video kampanye di Youtube. Media youtube ini didominasi oleh audiens remaja yang dapat dikategorikan sebagai swing voters dalam konsep politik. Oleh karena itu, penelitian ini bertujuan untuk mengetahui bagaimana kampanye audio visual dapat diterima oleh swing voters. Peneliti menggunakan metode Reception Analysis untuk melihat bagaimana audiens menerima paparan media. Hasil penelitian ini menunjukkan bahwa iklan kampanye Anies-Sandi diartikan sebagai egaliter oleh audiens, serta mampu menampilkan masalah SARA dengan konsep harmoni dan toleransi. Namun, iklan kampanye Anies-Sandi tidak memiliki pesan yang jelas karena pesan yang disampaikan sangatlah konseptual.
\end{abstract}

Kata Kunci:_Iklan Audio Visual, Reception Analysis, Kampanye Politik 


\section{PENDAHULUAN}

Dunia global saat ini sangat dipengaruhi oleh konten audio visual. Fenomena ini tentu sangat menarik untuk diperhatikan terutama oleh para akademisi, terkait dengan besarnya pengaruh dan luas paparannya di semua sisi kehidupan. Lebih lanjut, perkembangan tersebut memberikan perspektif baru di masyarakat, bahwa tanpa kehadiran aspek visual, kenyataan masih belum bisa dibuktikan.

Media komunikasi visual terutama film sudah ada sejak tahun 1800 Masehi. Hal ini terlihat dari hasil penelitian dalam bidang Biologi tentang gerak hewan. Penelitian ini berupa rangkaian gambar atau foto setiap pergerakan hewan dari sepersekian detiknya. Foto itu sendiri diambil menggunakan kamera foto berkecepatan tinggi. Lebih lanjut, media komunikasi visual ini mengilhami seniman jalanan untuk berkreasi dan menghasilkan karya yang mampu menghasilkan uang. Karya seniman jalanan ini berupa alat bernama praxinoscope. Alat ini mampu menampilkan rangkaian foto sehingga menampilkan suatu gerakan.

Perkembangan penting berikutnya adalah ditemukannya pita celluloid. Penemuan ini membuat teknologi film dikenal masyarakat. Munculnya teknologi ini membuat masyarakat mengenal budaya massa di teknologi komunikasi visual gerak, yang pada era sebelumnya hanya bisa diakses secara personal. Pada perkembangan selanjutnya, komunikasi visual bisa dinikmati tidak hanya dengan mengandalkan film, namun juga melalui iklan terutama iklan audio visual. Iklan audio visual dipercaya dapat memberikan pengaruh yang lebih besar ke masyarakat. Iklan ini juga mampu memberikan pesan yang lebih efektif dibandingkan iklan yang hanya menggunakan visual semata - misal iklan dalam media cetak. Hal ini sejalan dengan Donbasch (2008), yang menjelaskan bahwa promosi produk dan jasa bisa dilakukan dengan menggunakan iklan.

Iklan tidak hanya menyampaikan pesan produk tetapi juga digunakan untuk menyampaikan_pesan politik. Hal ini terlihat ketika banyak politisi mengunakan iklan untuk menyampaikan promosi partai, program dari partai, bahkan profil diri mereka sendiri. Secara lebih spesifik, iklan merupakan sarana kampanye, propaganda, dan sosialisasi yang efektif. Beberapa tokoh politik_pun memanfaatkan iklan sebagai alat untuk meraih perhatian massa, mewujudkan kepentingan pribadi, dan juga mewujudkan kepentingan partai pendukungnya.

Strategi ini pun juga dimanfaatkan oleh pasangan Anies-Sandi, untuk memenangkan kursi sebagai gubernur DKI Jakarta. Saat ini pasangan tersebut telah memenangkan perebutan jabatan tersebut dan hal ini semakin menunjukkan pada para tokoh politik bahwa iklan menjadi strategi efektif dalam berkampanye.

Iklan kampanye Anies-Sandi ditampilkan di media sosial Youtube dengan durasi dua menit. Hasil observasi yang dilakukan peneliti terhadap menu pencarian di Youtube, ditemukan bahwa iklan kampanye tersebut diunggah oleh pihak pendukungnya dan pihak netral yang memberitakan kontroversi dari iklan AhokDjarot sebagai pesaing mereka. Kontroversialnya iklan pesaing, yaitu kampanye Ahok-Djarot marak diberitakan, karena dalam kontennya menampilkan rekonstruksi kerusuhan 1998 yang memang pada saat itu etnis Tionghoa mengalami berbagai macam kekerasan serta menampilkan para demonstran 
berpeci dan bersorban membentangkan spanduk bertuliskan "Ganyang Cina". Peneliti tidak memasukkan analisis iklan pesaing, karena Iklan Anies-Sandi terbukti memberi sumbangsih dalam pemenangan calon ini, dan supaya penelitian lebih terfokus dalam menganalisis sumbangsih iklan dalam pemenangan calon.

Isi dari iklan Anies-Sandi bila dibandingkan dengan isi kampanye pesaingnya yaitu Ahok-Djarot, tidak menimbulkan kontroversi. Iklan AniesSandi menonjolkan budaya Betawi dan masyarakat Jakarta dengan latar musik menggunakan kesenian Betawi.

Penggunaan iklan sebagai strategi kampanye, membuktikan bahwa iklan merupakan salah satu sarana yang tidak bisa dipisahkan dari pengaruh politik dan ideologi. Dalam pengaruhnya, iklan mampu menjangkau semua usia, tidak terkecuali usia remaja. Usia remaja adalah usia pemilih pemula, yang pada rentang usia tersebut mereka merupakan target yang mudah dipengaruhi oleh iklan dengan pesan politik.

Pemilih jenis ini biasa disebut dengan early voter yang secara konseptual merupakan kelompok pemilih yang bisa disebut juga dengan 'floating voters', atau kelompok yang komitmennya terhadap pilihannya tidak kuat, cenderung tidak sulit untuk dipengaruhi, mudah setuju terhadap suatu gagasan, dan tidak memperhatikan pendapat lainnya (McNair, 2003). Keadaan seperti ini membuat floating voters pada umumnya menjadi sasaran mudah untuk diarahkan oleh pihak tertentu dalam politik. Kelompok yang cenderung menjadi sasaran ini lebih mudah menerima pesan dari iklan politis dalam pemilihan umum.

Kelompok ini memiliki sebaran usia diantara 17-25 tahun. Mudahnya kelompok ini menerima pengaruh ideologi politik tertentu karena mereka cenderung tidak mempunyai pengetahuan yang layak tentang politik dan hal-hal yang berhubungan dengan politik. Besarnya kuantitas rentang usia ini menjadi daya tarik yang besar bagi para elit politik untuk mendapatkan banyak dukungan. Keadaan ini juga sangat mungkin terjadi pada Pemilu DKI Jakarta 2017. Selanjutnya, pemanfaatan iklan sebagai strategi kampanye untuk meraih massa pemilih pemula juga melibatkan proses persepsi calon pemilih pada iklan tersebut. Pada rentang usia ini, pemilih cenderung memutuskan menentukan dukungan apabila menganggap iklan kampanye dari peserta pemilu tersebut menarik. Sebaliknya apabila mereka menganggap iklan yang diperlihatkan kepada mereka tidak menarik, maka kemungkinan besar mereka tidak akan terpersuasi. Sehingga, dapat dikatakan bahwa aspek persepsi merupakan hal penting dalam strategi persuasi dalam iklan.

Berdasarkan tinjauan tersebut, penelitian ini bertujuan untuk mengetahui sejauh mana iklan digunakan sebagai sarana kampanye dan alat komunikasi politik, juga bagaimana iklan dimanfaatkan untuk meraih massa pada kelompok pemilih pemula. Penelitian ini juga bertujuan untuk memahami bagaimana proses persepsi pemilih pemula terhadap iklan audio visual kampanye. Lebih lanjut, kegiatan penelitian ini sangat penting dilakukan mengingat pesatnya penggunaan sarana audio visual dalam berbagai media popular saat ini. Peneliti berusaha memberi gambaran tentang proses politik dalam dunia periklanan audio visual.

Hasil dari penelitian diharapkan dapat memberi pertimbangan bagi semua pihak yang berkepentingan, terutama yang 
berkepentingan dalam dunia politik untuk lebih mudah dan efektif dalam menyampaikan pesan di masyarakat . Hasil penelitian ini juga dapat dijadikan sebagai titik awal oleh pemilih pemula, politisi, dan masyarakat umum untuk mengetahui tentang kemampuan iklan sebagai strategi kampanye, dan juga kemampuan iklan sebagai media sosialisasi. Ke depannya, pengetahuan masyarakat ini sangatlah bermanfaat dalam mendukung perwujudan good governance.

Iklan mempunyai efek yang besar untuk masyarakat. Iklan membujuk masyarakat untuk menentukan pilihan pada suatu produk atau jasa tertentu. Pengaruh iklan yang besar tersebut membuat iklan digunakan sebagai sarana kampanye politik oleh para calon pemimpin daerah. Hal ini merupakan tanda masuknya iklan dalam dunia politik. Iklan politik merupakan salah satu sarana yang efektif dalam mempersuasi khalayak, karena iklan memiliki kecenderungan untuk tidak disaring oleh audience (Kaid, 2008). Oleh karena itu, khalayak cenderung memperoleh pesan iklan sesuai dengan harapan pengiklan atau politisi tertentu. Iklan politik menyajikan informasi yang berkaitan dengan pemilihan presiden, pimpinan daerah, atau informasi lain yang berkaitan dengan kepentingan kelompok tertentu. Kemudian, hadirnya iklan politik tidak terlepas dari proses berdemokrasi secara langsung dan kebebasan dalam memilih pemimpinnya (Perloff, dkk., 2008). Secara sederhana, dapat dianalogikan bahwa politisi mempromosikan diri mereka untuk dipilih masyarakat, seperti iklan yang mempromosikan barang dan jasa kepada masyarakat.
Iklan politik dituntut untuk mampu menghadirkan pesan-pesan yang bisa menarik perhatian khalayak. Selain itu unsur pesan adalah bagian penting untuk proses promosi, pada iklan. Para politisi sangat memperhatikan perancangan pesan iklan kepada khalayak. Beberapa pesan yang biasa muncul pada iklan politik adalah pesan-pesan terkait dengan propaganda, dan atau pesan politik yang mengarahkan masyarakat untuk menyetujui suatu konstruksi politik tertentu (Perloff, dkk., 2008). Lebih lanjut, para politisi menyampaikan pesan-pesan politik dengan menggunakan isu-isu yang sedang berkembang. Mereka juga berusaha untuk menanamkan suatu gambaran tertentu di benak khalayak tentang calon tertentu. Oleh sebab itulah, iklan politik cenderung mengarah ke manipulative, terutama pada aspek pesan politik. Aspek manipulatif dalam iklan politik sering disebut dengan "media buying"- pembelian media. Istilah ini mengarah kepada usaha dalam membentuk iklan politik oleh caloncalon pemimpin, sehingga mereka mampu memanipulasi isi pesan (William, 2008). Keadaan ini membuat satu kelompok tertentu cenderung menampilkan sosok calon untuk terlihat baik, hingga ada kemungkinan iklan tersebut merendahkan calon saingannya.

Penggunaan iklan untuk aktivitas politik praktis adalah usaha satu calon tertentu agar mampu mempromosikan agenda politik tertentu kepada masyarakat. Selain itu, tujuan utama iklan kampanye adalah untuk memasarkan calon politik. Iklan kampanye merupakan sarana efektif untuk memberikan penawaran satu calon pemimpin kepada masyarakat, sehingga mereka diharapkan memiliki ketertarikan dengan satu calon tertentu, yang pada 
akhirnya diwujudkan dengan munculnya keputusan memilih calon yang diiklankan..

Sebagaimana kita ketahui, setelah Orde Baru runtuh, media di Indonesia berkembang sangat pesat. Terlebih setelah era reformasi, penggunaan media semakin bebas. Demikian halnya pada konteks politik, media semakin intensif digunakan sebagai instrument politik. Terlebih pada era mediasi yang saat ini berlangsung, media digunakan sebagai alat kampanye.

Keadaan ini dapat dipahami, mengingat secara teoritis, media juga mengalami politisasi yang bisa dimanfaatkan secara kreatif oleh para politisi. Fungsi politik media diterangkan dalam Buku Komunikasi Politik, Media Massa dan Kampanye pemilihan yang ditulis oleh Pawito (2009). Ia mengutip Thomas R. Dye dan Harmon Zeigler, bahwa terdapat lima hal pokok fungsi politis media, yaitu, fungsi pemberitaan, interpretasi, sosialisasi, persuasi, dan pengagendaan isu (Pawito, 2009).

Setiap fungsi politis media ini mempunyai karakter tersendiri. Pertama, fungsi pemberitaan yang beroperasi di aktivitas pokok media, yaitu mengamati kejadian yang terjadi di masyarakat dan melaporkannya. Kedua, fungsi politis interpretasi, yaitu peran media massa dalam menafsirkan realita dalam bentuk informasi kepada public. Ketiga, fungsi sosialisasi yang mengarah kepada peran atau tindakan media massa untuk menyebarkan dan mewariskan nilai-nilai di masyarakat. Menurut Hamad (2010), kalau bisa diibaratkan sebagai sebuah ritual, terminology komunikasi pada perspektif ini dilakukan untuk merawat kebersamaan dan juga solidaritas di komunitas Keempat, yaitu fungsi persuasi, merupakan fungsi politik yang terlihat jelas, terutama pada waktu penyelenggaraan kampanye pemilihan, pilkada bupati, walikota, gubernur, atau bahkan presiden. Peristiwa politik ini selalu menjadi ajang media massa untuk aktif berpolitik, meliput dan membangun peristiwa politik untuk disajikan kepada masyarakatFungsi kelima adalah agenda setting, yaitu ketika media memberi penekanan tertentu kepada peristiwa atau isu yang diberitakan. Perhatian besar media kepada suatu peristiwa menunjukkan media mempunyai kepentingan tertentu. Hal ini berarti mengarah kepada teori agenda setting yang dikembangkan Maxwell McCombs dan Donald Shaw, media mempunyai kekuatan yang menentukan "apa yang penting" dan "apa yang tidak penting" untuk khalayak luas. Semakin sering informasi disajikan di media, maka pengaruhnya akan semakin kuat. Pemberitaan ini biasanya disajikan dengan memberi space, ruang atau waktu tayangan. Penempatan sebuah isu organisasi pada halaman depan atau penempatan urutan pemberitaan. Secara visual, hal ini mampu mempengaruhi persepsi publik.

Pemilihan Gubernur Jakarta yang dilakukan dua putaran ini telah dilaksanakan semua tahapnya dari 3 Agustus hingga 6 mei 2017. Peserta yang mengikuti terdiri dari tiga pasang calon gubernur dan calon wakil gubernur, yaitu pasangan Basuki Tjahaja Purnama (Ahok)Djarot Saiful Hidayat, selanjutnya pasangan Agus Harimurti YudhoyonoSylviana Murni, dan juga pasangan Anies Baswedan-Sandiaga Uno (Sari, 2016). Pemilihan Gubernur ini diwarnai dengan kasus dugaan penistaan agama oleh seorang calon Gubernur yaitu Basuki Tjahaya Purnama atau Ahok dan mengundang reaksi massa berupa protes 
dan rentetan aksi massa yang berlangsung massif di jakarta. Gerakan ini digagas oleh kelompok massa yang bernama GNPFMUI (Gerakan Nasional Pengawal Fatwa MUI) dan aksinya dikenal dengan gerakan 212.

\section{METODE PENELITIAN}

Penelitian ini merupakan penelitian deskriptif dengan pendekatan analisis isi dan Reception Analysis (analisis penerimaan) sebagai pendekatan ilmiah penelitian. Dengan menggunakan pendekatan ilmiah tesebut, peneliti berusaha memberikan gambaran tentang pendapat umum masyarakat (audience) yang berkaitan dengan fenomena yang diteliti, sehingga peneliti dapat memperoleh penjelasan dan deskripsi mendetail tentang permasalahan di masyarakat secara holistik. Metode yang digunakan dalam penelitian ini adalah metode kualitatif, dimana metode ini dipandang lebih efektif dalam menjelaskan hubungan antara dua fenomena dibandingkan menggunakan metode kuantitatif. Selain itu, metode kualitatif adalah metode penelitian untuk mendapatkan pemahaman dan juga penjelasan yang lebih mendalam tentang suatu fenomena sosial (Donbasch , 2008).

Tahap penelitian ini sendiri dibagi menjadi dua tahap. Tahap pertama adalah analisis isi pada iklan kampanye audio visual pasangan Anies-Sandi pada Pemilu Gubernur Jakarta tahun 2017. Tahap berikutnya adalah FGD yang dilakukan dengan tujuh pemilih pemula dari daerah DKI Jakarta .

\section{HASIL DAN PEMBAHASAN}

\section{Iklan Kampanye Calon Gubernur DKI Jakarta Anies Sandi}

Saat ini, iklan sering dipakai sebagai media kampanye karena dipandang sangat efektif untuk mendapat perhatian khalayak. Hal ini menjadi alasan dari calon gubernur DKI Jakarta dalam berkampanye untuk memperoleh perhatian dari pemilih, konstituen, dan juga pendukung. Begitu halnya dengan pasangan Anies-Sandi (Anies Baswedan dan Sandiaga Uno). Mereka juga menggunakan iklan politik sebagai sarana dan media kampanye. Fakta ini menunjukkan bahwa para politisi memahami potensi kekuatan iklan dalam mempersuasi masyarakat luas.

Iklan kampanye pasangan AniesSandi berdurasi dua menit. Iklan ini mempunyai sisi naratif dan banyak menampilkan sisi kebersamaan dan kerjasama antara anggota masyarakat. Mereka tidak hanya menampilkan aspek pencitraan yang cenderung dikemas dengan baik, tetapi juga mempunyai sinkronisasi yang baik antara aspek visual dan pencitraannya. Dalam iklan, mereka juga menampilkan sejumlah testimoni dari beberapa orang sebagai representasi anggota masyarakat.

Iklan pasangan Anies-Sandi ini memiliki 14 adegan, meskipun terdapat beberapa adegan yang diulang. Semua adegan yang ditampilkan tidak semua berkaitan dengan isu-isu popular yang ada di masyarakat, tetapi juga adegan yang menonjolkan kehidupan sehari-hari masyarakat Jakarta. Adegan pertama di iklan kampanye ini menampilkan keberagaman agama, suku, dan budaya. Kemudian, dilanjutkan dengan adegan rapat harian di lingkungan kampung, 
kehidupan keseharian masyarakat umum, dan hal-hal lain yang berkenaan dengan kehidupan yang terjadi sehari-hari masyarakat Jakarta. Adegan terakhir ditampilkan testimoni dari berbagai karakter yang merepresentasikan berbagai kalangan di masyarakat.

Secara konseptual, iklan kampanye Anies-Sandi menampilkan bentuk persatuan masyarakat. Mereka berusaha menonjolkan kesamaan dari setiap aspek yang ada di masyarakat dan tidak menampilkan masalah perbedaan yang kerap muncul dalam suasana pemilu seperti permasalahan kampanye Ahok dan gerakan 212 sebagai reaksi terhadap permasalahan tersebut. Iklan kampanye Anies-Sandi juga berusaha menyampaikan visi-misi mereka, serta mempopulerkan tagline yang dibawa oleh pasangan calon gubernur dan wakil gubernur tersebut.

$$
\text { Sebagaimana yang telah }
$$

dikemukakan sebelumnya, bahwa iklan kampanye Anies-Sandi tidak menampilkan isu konflik yang sedang terjadi pada waktu itu. Mereka lebih menampilkan kepemimpinan yang menghormati keberagaman dan harmoni dalam keberagaman. Pesan ini ditampilkan dengan memunculkan karakter tokoh agama islam dan nasrani. Secara tidak langsung, ini juga merupakan sindiran untuk pesaing pasangan ini yaitu AhokDjarot yang mempunyai masalah terkait kasus penistaan agama. Mereka menjanjikan terciptanya kedamaian dalam keberagaman etnis, dan kebahagiaan di masyarakat Jakarta. Kebahagiaan yang mereka janjikan dimunculkan dalam narasi yang berbunyi "bahagia kotanya". Tentunya, ini juga merupakansindiran untuk pesaingnya yang menghadapi konflik dengan sebagian warga terkait masalah penggusuran. Tampilan sindiran ini diperlihatkan dengan ditampilkannya sebanyak dua kali aktifitas rapat warga dari berbagai latar belakang, yang diselingi dengan senyuman-senyuman dari para peserta rapat yang menunjukkan musyawarah yang damai dan rukun. Lebih lanjut, dalam iklan juga ditampilkan AniesSandi menjanjikan tempat untuk LSM dan Ormas khususnya ormas Islam. Hal ini merupakan masalah yang ,muncul di pemerintahan sebelumnya, dimana terdapat ketegangan antarapesaing dengan beberapa ormas Islam. Terakhir, janji yang diberikan adalah pemberian fasilitas untuk industry kecil kreatif agar dapat berkembang, dan juga pemberian jaminan untuk pengembangan budaya lokal.

Sindiran yang muncul dalam iklan kampanye tersebut, mencerminkan adanya "Media Buying" yang oleh William G.C. dijelaskan bahwa politisi dalam media menampilkan figurnya secara baik dan menutupi kekurangannya dan juga bahkan menjatuhkan lawannya (William, 2008). Hal Ini juga terlihat dalam tampilan iklan kampanye pasangan tersebut dengan menampilkan kedamaian, kebahagiaan dalam beragam etnis, visualisasi tentang ormas dan atribut-atribut mengenai agama, tidak terkecuali atribut agama Islam.

Iklan kampanye ini juga menggambarkan apa yang dijelaskan oleh Perloff, Horowitz dan Petey (2008), bahwa pesan yang ditampilkan oleh pasangan calon Gubernur tentang keberagaman ini merupakan pesan yang bersifat politis, yang tidak berhubungan langsung dengan kebutuhan masyarakat dan permalahan faktual yang muncul di masyarakat. Tim sukses menampilkan iklan yang tidak bersinggungan dengan kebutuhan dan masalah di masyarakat. Ini dilakukan agar masyarakat setuju dengan konstruksi 
politik yang mereka usung yaitu tentang keberagaman (Perloff, dkk., 2008).

\section{Analisis Resepsi Iklan Anies - Sandi}

Iklan kampanye ini digunakan untuk melakukan persuasi kepada mayarakat, termasuk pemilih pemula. Hal menarik yang ditampilkan disini adalah penggunaan isu keberagaman sebagai pesan utama dalam kampanyenya. Pesan keberagaman ini disampaikan dengan ringan tanpa menampilkan konflik yang yang terjadi di tengah masyarakat yaitu masalah yang sedang mengarah kepada pasangan pesain mereka yaitu Ahok Djarot. Tentu saja, hal ini menarik perhatian sejumlah informan dalam FGD dan memunculkan beberapa persepsi dan pendapat tentang iklan kampanye ini.

Informan FGD, yaitu Eka mengatakan bahwa iklan kampanye AniesSandi menggunakan isu tentang keadilan dalam kampanyenya. Ia mengatakan,

"Dan itu di jadikan bisnis massa oleh Anies- Sandi. Jadi aku lihatnya ini tentang keberagaman, ........ Yang disebutkan oleh Anies-Sandi itu tidak menjual keberagaman tetapi juga keadilan. Itu yang dimaksud Anies-Sandi semua masyarakat JKT diayomi." (FGD dengan Eka, 15 September 2017).

Pendapat Eka mengarah kepada pemahamannya bahwa isu keberagaman yang disampaikan iklan kampanye AniesSandi mempunyai bentuk keberagaman yang berkeadilan. Eka menyampaikan pendapatnya bahwa iklan kampanye ini menunjukkan ketenangan dan kesantunan sehingga dalam proses nya kurang memiliki tekanan dalam persuasi.

"Kalau emang dari video sih kurang mengena sih. Kurang mengena itu sih menurut saya sendiri, saya pribadi nggak tahu yang lain gimana. Kalau melihat secara basis massa ya Sandi itu dari golongan menengah kebawah." (FGD dengan Eka, 15 September 2017).

Eka berpendapat bahwa iklan kampanye Anies-Sandi fokus pada aspek penting di daerah Jakarta, yang cenderung kurang diperhatikan oleh pimpinan DKI sebelumnya. Ia mencontohkan dengan adanya tampilan budaya Jakarta di dalam iklan.

Sejumlah informan dalam FGD memberikan sejumlah pendapatnya terhadap iklan kampanye Anies-Sandi, seperti yang dilakukan oleh Mario. Mario menjelaskan bahwa iklan kampanye AniesSandi menampilkan solusi terhadap sejumlah masalah di Jakarta.

“... Anies itu tuh di videonya kalau dia itu hadir sebagai solusi mengingat dinamika politik Jakarta yang waktu tu menyngkut masalah agama dan ras dia hadir sebagai penyelamat. ..." (FGD dengan Mario, 15 September 2017).

Pendapat di atas menunjukkan bahwa Mario memandang iklan kampanye Anies-Sandi tampil sebagai penyelamat, terutama bagi warga Jakarta yang terpinggirkan. Selain itu, iklan tersebut sekaligus muncul sebagai solusi untuk mengatasi masalah keberagaman dan dinamika politik yang relatif panas.). Ia menganggap iklan kampanye politik Anies-Sandi tampil secara lebih sederhana, serta menampilkan Jakarta yang lebih humanis.

Pendapat serupa disampaikan oleh Damar, ia menyampaikan bahwa iklan kampanye Anies-Sandi tampil dengan cara yang lebih egaliter, yaitu berusaha merangkul semua golongan yang selama 
ini tidak terlalu menjadi perhatian bagi pemerintah. Ia mengatakan:

"Nah kalau Anies walaupun prakteknya gatau gimana juga tapi kelihatan Anies mencoba merangkul semua bersama ini, bersama bangun itu, bangun ini." (FGD dengan Damar, 15 September 2017).

Lebih lanjut, Damar menyatakan bahwa ia sendiri belum mengetahui kinerja AniesSandi sebagai gubernur dan wakil gubernur, namun dari iklan kampanye milik mereka, tampaknya mereka berusaha menampilkan aspek keadilan dengan cara merangkul semua kelompok masyarakat.

Hal serupa diungkapkan oleh Mila, salah satu informan dalam FGD. Mila mengatakan:

"menurut saya sih anies sandi karena dia terkesan merangkul, dari pembawaan iklan tersebut tenang, lembut, jadi kita tuh berfikir jadi tenang apa yang diomongkan iklan tersebut." (FGD dengan Mila, 15 September 2017).

Menurutnya, iklan kampanye Anies-Sandi berupaya maksimal menunjukkan aspek kebersamaan, serta keadilan yang merata bagi masyarakat Jakarta secara umum. Selain itu, pesan iklan yang lebih tenang (tidak terlalu menggebu) menjadikan masyarakat dapat berpikir jernih dalam mencerna pesan iklan. Dengan begitu, memungkinkan masyarakat mendapatkan pesan yang lebih komprehensif dan jelas, sehingga audiens tertarik untuk memilih Anies-Sandi.

Dari hasil FGD tentang iklan Audio Visual, dapat ditarik kesimpulan bahwa iklan audio visual oleh Anies Sandi mencerminkan adanya aspek "Media Buying" yaitu mereka menampilkan sosoknya secara baik, menutupi semua kekurangan bahkan hingga menjatuhkan lawannya (William, 2008). Apa yang dilakukan oleh tim sukses Anies-Sandi yang menampilkan sindiran-sindiran halus serta menampilkan kedamaian, kebahagiaan dalam beragam etnis, visualisasi tentang ormas, dan atributatribut agama tidak terkecuali atribut Islam, adalah bentuk dari strategi iklan Anies-Sandi.

\section{PENUTUP}

\section{Simpulan Dan Saran}

Penjelasan dan analisis data pada bab sebelumnya, menunjukkan setidaknya empat temuan utama dan satu kesimpulan besar. Pertama, iklan kampanye AniesSandi cenderung ditampilkan dan diterima khalayak sebagai iklan yang berisi nilai egaliter, serta menampilkan isu tentang SARA melalui perspektif kerukunan, tenggang rasa, dan toleransi. Meskipun demikian, iklan kampanye Anies-Sandi menurut khalayak tidak menyajikan pesan secara tegas sehingga masih terkesan tampil secara konseptual. Kedua, content dari iklan audio visual ini bermuatan politis dan tidak berdasar pada fakta dan permasalahan di lapangan dan bertujuan membuat masyarakat setuju dengan konstruksi politiknya. Ketiga, iklan kampanye dari Anies-Sandi mencerminkan praktik Media Buying, menampilkan sosoknya dengan sangat baik dengan menutupi kekurangan serta menyindir lawan politiknya dengan tujuan menjatuhkan pesaingnya tersebut. Keempat, perkembangan iklan Audio Visual yang berhubungan dengan politik saat ini cenderung memiliki persaingan yang terletak pada content yang sangat politis dalam iklan yang disajikan.

Kesimpulan utama dari penelitian ini yaitu iklan kampanye rupanya terikat 
penuh dengan sejumlah isu yang sedang berkembang di masyarakat. Hal itu menjadikan iklan kampanye tidak hanya digunakan sebagai sarana memasarkan program-program politik, dan sosok calon pemimpin semata, tapi juga sarana menanamkan isu-isu penting ke dalam benak masyarakat, seperti isu tentang SARA, budaya, hingga ideologi. Sederhananya, iklan politik merupakan alat efektif bagi elit-elit politik untuk menanamkan sejumlah pesan dan ideologi tertentu kepada audien demi kepentingan kelompok atau golongan.

\section{DAFTAR PUSTAKA}

Donsbach, W. 2008. The International Encyclopedia of Communication. Blackwell Publishing. Oxford.

Hamad, Ibnu. 2010. Komunikasi Sebagai Wacana. La Tofi Enterprise. Jakata.

Irianto, H, Bungin, B. 2001. Pokok-Pokok Penting Tentang Wawancara. dalam Burhan Bungin (editor) Metodologi Penelitian Kualitatif, Aktualisasi Metodologis ke Arah Ragam Varian Kontemporer. 108-132. Raja Grafindo Persada. Jakarta.

Jensen, K.B. \& Jankowski, N.W. 2002. A Handbook of Qualitative Methodologies for Mass Communication Research. Routledge. London.

Kaid, L. L. 2008. Political Advertising. dalam Wolfgang Donsbach (editor) International Encyclopedia of Communication: 3664-3667. Blackwell Publishing. Malden.

McNair, B. 2003. An Introduction of Political Communication. Third Edition. Routledge. London.
Perloff, R. Horowitz, E, M. \& Pettey, G.R. 2008. Persuation, Political. dalam Lynda Lee Kaid dan Christina HoltzBacha (editor) Encyclopedia of Political Communication: 547-549. Sage. Thousand Oaks.

Pawito. 2009. Komunikasi Politik, Media Massa dan Kampanye Pemilihan. Jalasutra. Yogyakarta.

William, G. C. 2008. Media Buying in Politics. dalam Lynda Lee Kaid dan Christina Holtz-Bacha (editor) Encyclopedia of Political Communication. Sage. Thousand Oaks.

Sari, N. 2016. Mekanisme Pengundian Nomor Urut Cagub-Cawagub pada Pilkada DKI 2017. https://megapolitan.kompas.com/rea d/2016/10/25/13125861/mekanisme. pengundian.nomor.urut.cagubcawagub.pada.pilkada.dki.2016 